Pawet Stawarz

Uniwersytet Warszawski

\title{
The impact of the Second Karabakh War on Azerbaijan's position in the South Caucasus - opportunities and threats
}

(Paper presented at the International Scientific Conference "New Order and law in the Caucasus: threat, risk and transformation (After the secound Karabakh War)" organized on December 5, 2020 by the STEM Analytical Center (Azerbaijan))

zerbaijan, due to the size of its territory, population, energy resources and the fact that
the infrastructure for their extraction and transport is not under Russia's control, is a key country in the region. Therefore, taking into account the subject of the conference, a very important issue is Azerbaijan's position in the South Caucasus. The results of the Second Karabakh War are very important for Azerbaijan's position in the South Caucasus. After Armenia took control of part of its territory illegally after the war in the first half of the 1990s, Azerbaijan's position weakened. From that moment on, the country's efforts to regain control of Nagorno-Karabakh and the adjacent territories in order to remove the situation that weakened the country internally and internationally, especially in the South Caucasus. Numerous diplomatic efforts and UN resolutions did not bring any effect. Only the results of the Second Karabakh War brought about changes. After regaining control over the southern part of Nagorno-Karabakh and its adjacent territories, the facts as regards the territory of Azerbaijan largely correspond to the state of international law. Clearly, this situation strengthens the state internally, significantly restricting the territory beyond the control of the government. In the international aspect, it shows the effectiveness of government actions. The terms of the truce are the result of, among others previous diplomatic activities carried out since the 1990s, those that did not directly bring the expected results, but by raising international awareness of the situation related to the illegal takeover of Nagorno-Karabakh by the Armenians, probably facilitated the achievement of the current effects. In order to strengthen Azerbaijan's position in the South Caucasus and in the international arena in general, it is also very important that the arrangements made agree with the Azerbaijani side, recognizing its arguments in the dispute with Armenia, which was de facto recognized as an aggressor illegally occupying another country's territory. 
It is worth noting, however, that the northern part of Nagorno-Karabakh and the socalled the Laczyński corridor still remains outside the effective authority of the government in Baku and their final status is to be determined later.

Considering the above, a question should be asked whether the arrangements after the Second Karabakh War will be permanent and constitute the final solution to the conflict, or will they only become a temporary calming down of the situation. A very important issue in this regard is settling the issue of the northern part of Nagorno-Karabakh as soon as possible, which should also return to the de facto power of Baku. An important element is also the behavior of Russia, whose troops are to secure the implementation of the arrangements made. It is also worth noting that the Turkish army is not part of the peacekeeping forces.

As it has already been indicated, as a result of the conditions of the truce, Azerbaijan's situation regarding control over its own territory, has improved significantly. However, this does not mean that all potential hot spots have been eliminated. First, part of NagornoKarabakh is still beyond Azerbaijan's control. Another element of this type is the Laczyński corridor, a $5 \mathrm{~km}$ strip of territory intended to serve as a link between Yerevan and Stepanakert, located in the northern part of Nagorno-Karabakh. As the history of many countries shows, such solutions do not contribute to the stability of the situation. Currently, the greatest challenge is the appropriate conduct of negotiations to complete the process of taking actual control over the entire territory of the state as quickly and without conflict as possible, which is natural from an international legal point of view.

An important element in stabilizing the situation is also the Russian army, which is supposed to maintain peace. It depends on their behavior and the policy of the Russian Federation whether they will be perceived as a neutral mediator or an ally of one of the parties to the conflict. Of course, in the latter case, it would have a destabilizing effect on the situation in the region. It seems that for the sake of the stability of the situation, it would be good if the conciliation troops consisted not only of the Russian army but also, for example, of Turkish soldiers. However, this did not happen, which proves Russia's dominant role in the South Caucasus as an external power. Another danger is the very fact that foreign troops are on the territory of Azerbaijan, although, according to declarations, they are only intended to maintain peace. The situation in Armenia is also worrying, where the inhabitants do not want to come to terms with the current realities and Prime Minister Nikol Pashinyan will probably be dismissed.

As you can see, the current situation greatly strengthens Azerbaijan's position in the South Caucasus region and gives prospects for regaining full control over its own territory, 
which would ultimately resolve the conflict. However, it should be remembered that the current realities are not free from potential hot spots. 